\title{
UNIVERSITYOF
}

FORWARD

THINKING

WESTMINSTER用

WestminsterResearch

http://www.westminster.ac.uk/westminsterresearch

Beyond the pregnant man: representing trans pregnancy in A

Deal With The Universe

Pearce, R. and White, F.R.

This is an accepted manuscript of an article published by Taylor \& Francis in Feminist Media Studies, 19 (5), pp. 764-767.

The final definitive version is available online:

https://dx.doi.org/10.1080/14680777.2019.1630925

(C) 2019 Taylor \& Francis

The WestminsterResearch online digital archive at the University of Westminster aims to make the research output of the University available to a wider audience. Copyright and Moral Rights remain with the authors and/or copyright owners.

Whilst further distribution of specific materials from within this archive is forbidden, you may freely distribute the URL of WestminsterResearch: ((http://westminsterresearch.wmin.ac.uk/)).

In case of abuse or copyright appearing without permission e-mail repository@westminster.ac.uk 


\section{Beyond the pregnant man: representing trans pregnancy in $A$ Deal With The Universe}

Ruth Pearce ${ }^{\mathrm{a}}$ and Francis Ray White ${ }^{\mathrm{b}}$

a School of Sociology and Social Policy, University of Leeds, Leeds, UK;

$\mathrm{b}$ School of Social Sciences, University of Westminster, London, UK

Published online $13^{\text {th }}$ June 2019

Every achievement of the past is cancelled out by the need to label the next achievement the 'first', making the framing of trans the framing of something exotic, different, a symptom of the modern age, rather than as just another aspect of human nature. (CN Lester 2017, 146)

March 26 2018: A powerful atmosphere of anticipation suffuses the sumptuous BFI Southbank auditorium as people slowly gather for the sold-out premiere and centre-piece screening of Jason Barker's documentary A Deal With The Universe (2018). It feels, as the BFI Flare LGBTQ+ film festival often does, like a family gathering. In the case of this film, that seems particularly apt.

A Deal With The Universe is described on the Tigerlily Productions website as 'Jason's incredible story of how he came to give birth to his child' (Parrot, 2018). A key promotional image for the film, especially for its wider UK cinema release in 2019, prominently features the heavily pregnant Barker in a swimming pool, bare chest and bump equally prominent above his swimming shorts. Like much of the written and visual language employed to signify trans pregnancy within mainstream media, such imagery relies on the "extraordinary" juxtaposition of bodily features normatively associated with men and women. What is truly unusual about Barker's film, however, is how it deviates from a now-standard narrative of the "pregnant man". 
This is an Author's Original Manuscript of an article published by Taylor \& Francis in 2019.

Feminist Media Studies, 19(5): p764-767.

Available online at: https://doi.org/10.1080/14680777.2019.1630925

In 2008, a wave of international interest in the story of Thomas Beatie established the template for mainstream media representations of trans pregnancy. American father Beatie was widely descripted as the pregnant man, with the definite article serving to highlight the supposed novelty of his choice to bear children. While Beatie's story did serve to raise awareness of the fact that trans people can retain their reproductive capacity even after undergoing forms of medical transition, it also paradoxically worked to erase, or smooth out the messier realities of trans reproduction and parenthood. In being portrayed as "the" pregnant man, Beatie was also wrongly represented as the first and the only. ${ }^{1}$ Consequently, the story focused more on the sensation of Beatie's appearance and the supposed paradox of male pregnancy, than on his actual experiences, motivations, hopes, dreams, fears and anxieties. In becoming an icon, Beatie lost something of his humanity.

Subsequent media reporting on trans pregnancy has continued to rely on the trope of novelty, even with Beatie's story already in the public consciousness. Other countries, including Germany, Finland and Israel, followed the US with home-grown "first pregnant men" stories. The UK has had not one, but two "first" pregnant men, announced in both 2012 and 2017 (Michael Toze 2018). This reporting represents a phenomenon Lester $(2017,146)$ has described as "the shock of the new", which reflects a wider tendency towards sensationalism and narrow, predictable narratives in media reporting on trans issues. Lester draws on the examples of Lily Elbe (subject of heavily-fictionalised 2015 biopic The Danish Girl) and Caitlyn Jenner to show how cultural amnesia around trans issues relies on the active production of ignorance. Consequently "it is not that trans people are ignored entirely, but that [stories] taught as fact can often obscure and distort the truth in a way that even silence could not" (Lester 2017, 5).

The production of ignorance through the "shock of a new" can also reflect an intentional prioritisation of sensation over truth. This was illustrated in a research interview undertaken by the lead author as part of the ongoing Trans Pregnancy project. ${ }^{2}$ The interviewee was one of several expectant trans parents approached by a British tabloid immediately prior to the publication of the country's second "first pregnant man" story in 2017. ${ }^{3}$ He explained: "I'd warned them, like, 'If you publicize it like that, you're going to look like idiots. Because that is not true' [. . .] and they were like, 'Oh no one'll know, it'll be fine. I don't care'".

While the marketing material surrounding A Deal With The Universe nods somewhat to these trends, the film itself proudly transcends them. At the premiere, Barker himself wryly commented that people expecting to see a film about a "pregnant man" were bound to be disappointed, given they were presented with a film actually about a "not-pregnant, not-man". Rather than revelling in the spectacle of the pregnant trans body, Barker's film 
This is an Author's Original Manuscript of an article published by Taylor \& Francis in 2019.

Feminist Media Studies, 19(5): p764-767.

Available online at: https://doi.org/10.1080/14680777.2019.1630925

draws on years of home video diaries that tell a story of the beauty, love, mirth and sorrow of everyday life. It locates the extraordinary in the mundane: cleaning a caravan, dealing with dead pigeons and misbehaving cats - and dozens of failed attempts to conceive. In this context, Barker's reflections on sex, gender and trans experience (what are the limitations of medical transition? what does it mean to transcend binary norms?) are contextualised within the far broader scope of his desires, pursuits and deep relationship with his partner Tracey. Indeed, Tracey's story is central to the film's neat de-exceptionalisation of trans pregnancy and particularly the intense association of trans people with hormones and surgery. Tracey's experiences of both hormone treatment and surgery in the course of breast cancer treatment serve as a counterpoint to assumption that these are issues only relevant to trans practices of reproduction.

For the queer and trans people attending the screening, there was a rare opportunity to see our lives reflected in three dimensions, while also offering a new perspective and thoughtful commentary on matters of desire, loss and parenthood. The audience reacted with clear delight, laughing loudly during the many moments of levity, and offering a standing ovation at the end.

Importantly, though, A Deal With The Universe is not unique in this regard. There has been an enormous growth in trans art and media-making in recent years; this extends to the topics of pregnancy and parenthood, where Barker's film exists alongside works such as the Masculine Birth Ritual podcast, ${ }^{4}$ and Trevor MacDonald (2016) book on childbirth and chestfeeding, Where's The Mother? Stories from a Transgender Dad. Cis audiences, too, seem increasingly interested in trans stories that humanise their subjects while also touching on universal themes of partnership and parenthood; while Barker's film tells what is perhaps a uniquely complex story, it exists within an emerging genre of trans pregnancy documentaries that also includes works such as A Womb of Their Own (2017), Sununú: The Revolution of Love (2017), and Seahorse (2019). This lineage can be traced back to Transparent (2005), a US documentary about trans birth parents that ironically pre-dates the origins of the "first pregnant man" narrative by several years.

\section{Acknowledgments}

The Trans Pregnancy Project is funded by the UK's Economic and Social Research Council (ESRC). The authors wish to thank project co-Investigator Damien W Riggs for his comments and feedback on an early draft of this commentary, and colleagues Sally Hines, Carla Pfeffer and Elisabetta Ruspini for their support.

\section{Funding}

This work was supported by the Economic and Social Research Council: [Grant Number ES/ N019067/1]. 
This is an Author's Original Manuscript of an article published by Taylor \& Francis in 2019.

Feminist Media Studies, 19(5): p764-767.

Available online at: https://doi.org/10.1080/14680777.2019.1630925

\section{Notes}

1. Trans birth parents have, of course, always existed. They have also long been present in the media (Patrick Califia 2000) and in academic literatures (Sam Dylan More 1998; Leslie M. Lothstein 1988).

2. http://transpregnancy.leeds.ac.uk/.

3. This was a semi-structured qualitative interview, one of approximately 50 being undertaken with parents who gave birth after coming out and/or beginning a transition by members of the Trans Pregnancy Project in Australia, Canada, the US and European Union countries (including the UK). Participants are recruited through trans community events, online groups for trans birth parents, and snowballing.

4. https://www.masculinebirthritual.com/.

\section{References}

Califia, Patrick. 2000. "Family Values." Village Voice, June 20. Accessed April 26, 2019. https:/www. villagevoice.com/2000/06/20/family-values/

A Deal With The Universe. 2018. Film. Directed by Jason Barker. UK: Delaval Film.

Lester, C. 2017. Trans like Me: A Journey for All of Us. London: Virago.

Lothstein, Leslie M. 1988. "Female-To-Male Transsexuals Who Have Delivered and Reared Their Children." Annals of Sex Research 1 (1): 151-166.

doi:10.1007/BF00852888.

MacDonald, Trevor. 2016. Where's the Mother? Stories from a Transgender Dad. Manitoba: Trans Canada Press.

More, Sam Dylan. 1998. “The Pregnant Man-An Oxymoron?” Journal of Gender Studies 7 (3): 319-328. doi:10.1080/09589236.1998.9960725.

Parrott, Nikki. 2018. "A Deal with the Universe to Premier at BFI Flare Film Festival". Tigerlily Productions. Accessed April 26, 2019.

http://www.tigerlilyproductions.com/blog/2018/2/22/ a-deal-with-the-universe-topremier-at-bfi-flare-film-festival

Seahorse. 2019. Film. Directed by Jeanie Finlay. UK: Grain Media.

Sununú: The Revolution of Love. 2017. Film. Directed by Olivia Crellin. Ecuador.

Toze, Michael. 2018. "The Risky Womb and the Unthinkability of the Pregnant Man: Addressing Trans-Masculine Hysterectomy." Feminism \& Psychology 28 (2): 194-211. doi: $10.1177 / 0959353517747007$.

Transparent. 2005. Film. Directed by Jules Rosskam. US: Mamsir Productions.

A Womb of Their Own. 2017. Film. Directed by Cyn Lubow. US: Serious Play Films. 